\title{
ELECTRIC PROPULSION FOR NEAR COASTAL SHIPS
}

\section{*NOURHAN I. GHONEIM ${ }^{1}$, MOHAMMAD REZA ZAFARI ANARAKI ${ }^{2}$, MOHAMED SHOUMAN $^{3}$, KAMBIZ MOKHTARI $^{4}$}

\author{
${ }^{1}$ Assistant Professor, International Maritime College Oman IMCO, Sultanate of Oman \\ ${ }^{2}$ Lecturer, International Maritime College Oman IMCO, Sultanate of Oman \\ ${ }^{3}$ Assistant Professor, Marine Engineering Technology Department, Arab Academy for Science, \\ Technology and Maritime Transport, Egypt. \\ ${ }^{4}$ Assistant Professor, International Maritime College Oman IMCO, Sultanate of Oman
}

\begin{abstract}
The increase in the fuel costs all over the world and in Oman, caring for air and sea against pollution by fossil fuels and the increase of health issues caused by the excessive noise produced by the internal combustion engines and safety enhancement in the shipping industry are the main reasons have encouraged us to investigate a new source of power for near coastal ships within Sultanate of Oman.

Replacement the fuel tanks of these ships by rechargeable Lithium-ion batteries that can be charged fast and safely and also replacement the engines by low voltage reversible Alternative Current, AC. motors which are able to deliver different ranges of speed and power to the propeller.

Also, the ship is able to be equipped with a solar cell; the solar energy can charge the batteries or rotate the electric motor directly. Each square meter of the commercial solar cell is able to provide $100 \mathrm{~W}$ of electricity. Sunny weather of Oman is a good incentive to achieve that.
\end{abstract}

KEYWORDS: Fishing, Electric Propulsion, Oman, Coastal Ships

Received: Jul 27, 2020; Accepted: Aug 17, 2020; Published: Sep 28, 2020; Paper Id.: IJNADEC20201

\section{NOMENCLATURE}

$\begin{array}{ll}\text { AC } & \text { : Alternative Current } \\ \text { BMS } & : \text { Battery Management System } \\ \text { CO } & : \text { Carbon monoxide } \\ \text { DC } & : \text { Direct Current } \\ \text { Hp } & \text { : Horse Power } \\ \text { kW } & : \text { Kilowatt }\end{array}$

${ }^{1}$ Assistant Professor, International Maritime College Oman IMCO, Sultanate of Oman

${ }^{2}$ Lecturer, International Maritime College Oman IMCO, Sultanate of Oman

${ }^{3}$ Assistant Professor, Marine Engineering Technology Department, Arab Academy for Science, Technology Maritime Transport, Egypt.

${ }^{4}$ Assistant Professor, International Maritime College Oman IMCO, Sultanate of Oman 


\section{LCD : Liquid Crystal Display \\ $\mathrm{NO}_{\mathrm{x}} \quad$ : Nitrogen oxides \\ RPM : Revolution Per Minute \\ $\mathrm{SO}_{2} \quad$ : Sulfur dioxide \\ HEB : Hybrid Electric Boat}

\section{INTRODUCTION}

One of the important activities in Oman is fishing. Oman has a long coastline for its population and the fishing on the coast of Oman is not fully mechanized.

The conversion of traditional fishing to industrial has advantages and disadvantages. When fishing is mechanized and industrialized, the total cost is reduced and the fish are at a lower cost to the customer and even available for export to the market. But, on the other hand, it can damage aquatic resources and, for the long run, reduce these resources on the coast of the country.

Failure to do industrial fishing has always made these beaches rich in marine resources. Oman fishermen do not need advanced equipment to get these resources. Since the energy in the Gulf area is cheaper than other parts of the world, it is also easy to navigate water resources. No effort has been made to optimize fishing.

Almost all small ships and boats sailing on the coast of Oman have internal combustion engines that use fuels such as gasoline and diesel oil. The sailing range of these types of ships are twenty miles from the coastline except for ships designed for specific missions such as tugboats or search and rescue boats, the rest of Oman's near coastal ships/boats use light engines for their propulsion or electricity generation. The light engines range is between $20 \mathrm{Hp}$ to 200 $\mathrm{Hp}(15 \mathrm{~kW}$ to $150 \mathrm{~kW})$.

Considering the size of the engines and the distances that each ship wishes to navigate, the means of propulsion of these ships to the electric propulsion can be verified.

Fuel tanks of these ships are replaced by rechargeable Lithium-ion batteries that can be charged fast and safely, and the engines are replaced by low voltage reversible AC. motors. the AC motors are able to deliver different ranges of speed and power to the propeller.

Our suggestion is to replace the engine with two electric motors with the power half of the engine power. By using two electric motors, the efficiency of the system will be upgraded and will provide better maneuverability to the ship. Two motors can also make the ship safer and more redundant. With two electric motors, the failure of one motor does not put the ship out of operation because the second motor is still able to move the ship. Electric motors give us such freedom of action without imposing an extra charge on us.

Because of the ability of the ship for the equipped solar cell, so, the batteries can be charged or the electrical motor can be rotated directly using the solar energy. 100W of electricity can be provided by one square meter of the commercial solar cell. Figure No.1 shows an example of a marine battery. Whether, Figure No.2 and Figure No.3 show an example of a boat with Solar Cell and land Solar Cell. 


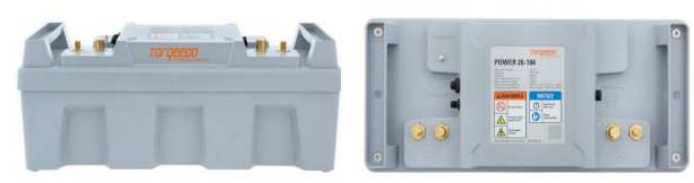

Figure 1: Marine battery [1]

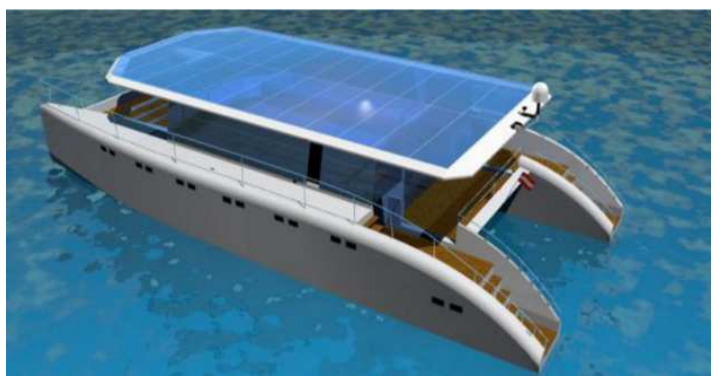

Figure 2: Boat with Solar Cell, [2]

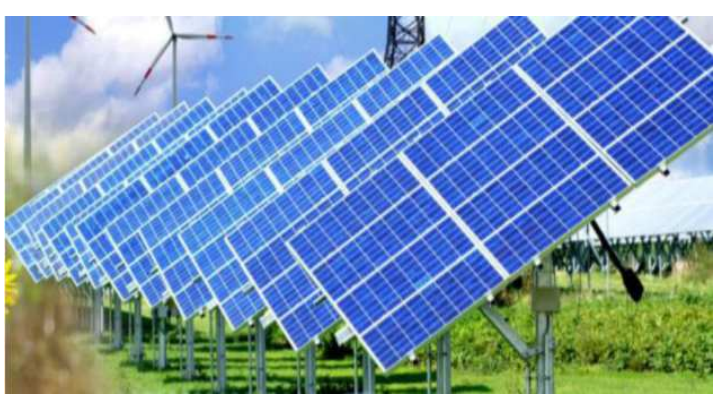

Figure 3: Land Solar Cell, [2]

\section{OBJECTIVES}

In this paper, the authors attempt to examine the benefits of changing the thrust system of small fishing vessels from gasoline to electric from different angles.

\section{LITERATURE REVIEW}

Leśniewski et al. discussed the modern technologies' development and their availability increasing and also the reduced costs of power sources and highly efficient systems of propulsion, which resulted in hybrid or electric propulsion systems' rising popularity to be used on watercraft. They presented lab tests and design of a propulsion system of prototype parallel hybrid. It describes a concept of retrofitting a conventionally powered $9 \mathrm{~m}$ long ship with the system and includes efficiency and power measurements' results, as well as calculations of the vessel's operating range under the propulsion of its electric motor. Studied as well as the concept of solar panels array addition, [3].

Obaid et al. proposed a design of hybrid power system that consists of three main components. A three-phase asynchronous machine is driven by using the hybrid system by continuous power supplying for the electric motor of the boat regardless the weather conditions' changes which are challenging to systems' solar power resulting from the solar irradiance levels' changes which are affected by wind speed, humidity and temperature. The overall hybrid system consists of three main components that are solar power from Photovoltaic (PV) array that has Maximization Maximum Power Point Tracking (MPPT) system, fuel cell of type Polymer Electrolyte Membrane (PEM) with water electrolysis to produce hydrogen for the operation of fuel cell and diesel generator which uses diesel oil to operation. The continuous operation of the presented system was tested by solar irradiance forecasting was considered by using Neural Network regardless the 
weather conditions' changes. The control of the fuel cell operation was done by fuzzy logic energy management with respect to the charge's battery state. The simulations of SIMULINK and MATLAB will show the proposed system's performance by blocks of SIMULINK. Regardless the weather conditions' changes, the continuous operation will be shown, [4].

Antoniuk, Alexei V. et al. deals with an electric-driven shipborne launching device's design. Development of a full providing device for efficient and safe lifting, maintaining and lowering of an auxiliary boat of the ship is the aim of their paper. First part discussed briefly davits' different types. Next part is devoted to the variable mechanical load's calculation; the device's features of the operation and construction were taken into account. Then, they selected the suitable electric motor. Finally, they performed electric drive operation analysis and simulation of the lifting device onboard, [5].

Leung, C. P. et al. presented a paper of Zero emission solar-powered boat development. Scientists, academics and industries in the past decades put huge afford for solar-powered cars' development and research. The development of solarpowered vessels has been overlooked. The engine-powered vessels' pollutions have not been seriously concerned. Engine powered vessels also create significant environmental pollutions, especially for oil and air pollutions except for the engine powered vehicles. Recently, the solar-powered cars' technology became mature. This is a right moment for the development of solar-powered vessels. Their paper provides solar-powered boat development's discussion, design and analysis, [6].

Ancient technique of fishing practice, all over the world, most of the developing countries that fishing net indicator is night fishing's important component. Fishermen in Bangladesh use inefficient kerosene based lamp, pollutes the environment and costly. A model is proposed in in this model to replace the kerosene lamp with LED light feed by solar energy. The system of solar-LED has desirable features as environmental zero pollution, reduces the fossil fuel dependency by saving a large amount of fuel from a single mechanized boat and low cost. Life Cycle Cost Analysis (LCCA) was analyzed for assessment the proposed system economic feasibility, [7].

Camara, M.B. et al. present improvement of energy management for applications of a Hybrid Electric Boat (HEB) by the usage of frequency approach. A lithium-battery assists a variable speed Diesel-Permanent Magnet Generator (Diesel-PMG) to satisfy the demand of energetic of HEB. The DC-bus is connected to a module of lithium-battery by a converter of buck-boost, and that of the variable speed Diesel Generator, it is connected to DC-bus by the usage of three phase controlled rectifier. The two electric motors connected to two DC/AC converters are used as system's thruster that enables to emulate Hybrid Electric Boat's (HEB) energetic demand in operations of propulsion. The thrusters' power requirement is added to demand of embedded appliances to find profile of load. Their paper's contribution is focused on profile of load sharing between a Lithium-battery and variable speed Diesel Generator according to the sources' dynamic responses. The proposed method's performances are evaluated using MATALB/Simulink software and experimental tests in reduced scale through some simulations, [8].

The recently trend among the manufacturers of low speed electric vehicle for update batteries of traction from heavy and older chemistries to lighter and new batter chemistries. A Club Car Villager LSV electric golf cart in this viability study was converted from the original flooded lead acid batteries to hard carbon/mixed oxide lithium batteries. The range and speed of both chemistries arc compared. This paper demonstrates a potential operational savings for the users of light electric vehicle. The lithium batteries outperformed the lead acid in both charging time (95\% reduction) and 
range (46.7\% increase) despite a volume reduction. The range increase was due, in part, to battery weight reduction of $62.5 \%$. Also, they discussed the lithium battery management system's implementation and J1772 charger system used for supporting this conversion in addition to results of range test, [9].

Bellache, K. et al. present improvement of energy management for applications of a Hybrid Electric Boat (HEB) by the usage of frequency approach. A lithium-battery assists a variable speed Diesel-Permanent Magnet Generator (Diesel-PMG) to satisfy the demand of energetic of HEB. The DC-bus is connected to a module of lithium-battery by a converter of buck-boost, and that of the variable speed Diesel Generator, it is connected to DC-bus by the usage of three phase controlled rectifier. The two electric motors connected to two DC/AC converters are used as system's thruster that enables to emulate Hybrid Electric Boat's (HEB) energetic demand in operations of propulsion. The thrusters' power requirement is added to demand of embedded appliances to find profile of load. Their paper's contribution is focused on profile of load sharing between a Lithium-battery and variable speed Diesel Generator according to the sources' dynamic responses. The proposed method's performances are evaluated using MATALB/Simulink software through some simulations, [10].

Yildiz et al. have performed a project for the purpose of demonstration the conversion of an 18' Pursuit 2000 S2 gasoline-powered boat into a Hybrid Electric Boat (HEB). Also, for replacement a non-working Evinrude 225 V6 outboard engine with an efficient electric motor and battery-powered completely. A leisure boat was created to be used in lakes and rivers to demonstrate the steps of conversion of gasoline-to-hybrid and for measurement the efficiency of the boat after testing. The team defined the guidelines of the project which were realized in a zero-impact and green boat. The boat is powered after conversion by deep-cycle batteries which can be charged by a hydrogen fuel cell unit and modules of solar. For harvesting of energy and management of power, the group constructed a power box that contains all control devices, including motor controllers and charge, fuses, start I stop switches, a fuel cell unit, data acquisition and monitoring devices, a power switch and a start-up battery, [11].

\section{PROSPECTS STUDY OF THE SUBJECT}

\subsection{Economical}

The gasoline prices in some countries are shown in Table No.1.

Table 1: Gasoline Price, [12]

\begin{tabular}{|c|c|c|c|c|c|c|c|}
\hline Country & India & $\begin{array}{c}\text { Pakista } \\
\mathbf{n}\end{array}$ & France & $\begin{array}{c}\text { Denmar } \\
\mathbf{k}\end{array}$ & Canada & $\begin{array}{c}\text { South } \\
\text { Africa }\end{array}$ & $\begin{array}{c}\text { Oma } \\
\mathbf{n}\end{array}$ \\
\hline $\begin{array}{c}\text { Gasoline } \\
\text { price USD }\end{array}$ & 1.05 & 0.72 & 1.83 & 1.97 & 0.99 & 1.16 & 0.55 \\
\hline
\end{tabular}

Table No.2 compares the cost of day-trip fishing of the light-boats along the coast of Oman with some countries neighboring to Oman and on other continents. In this table, the basis for calculating is a short trip, in which an average of 50 liters of gasoline is consumed, is considered.

As Table No.2 shows, Pakistan is closer to Oman in the country's cost per liter. However, the cost of the Pakistani's fishing is still around \$ 250 per month higher than the cost of fishing in Oman. And the table also shows that the cost of fishing with a small gasoline float in Denmark is \$2,130 higher than the same in Oman. 
Table 2:Cost Comparison

\begin{tabular}{|l|c|c|c|c|}
\hline Country & $\begin{array}{c}\text { USD } \\
\text { Lite } \\
\mathbf{r}\end{array}$ & $\begin{array}{c}\text { Cost for a short } \\
\text { voyage (50 Liter) } \\
\text { USD }\end{array}$ & $\begin{array}{c}\text { Cost difference with } \\
\text { Oman per day }\end{array}$ & $\begin{array}{c}\text { Cost difference } \\
\text { with Oman per } \\
\text { month }\end{array}$ \\
\hline India & 1.05 & 75 & 47.5 & 1425 \\
\hline Pakistan & 0.72 & 36 & 8.5 & 255 \\
\hline France & 1.83 & 91.5 & 64 & 1920 \\
\hline Denmark & 1.97 & 98.5 & 71 & 2130 \\
\hline Canada & 0.99 & 49.5 & 22 & 660 \\
\hline South Africa & 1.16 & 58 & 30.5 & 915 \\
\hline Oman & 0.55 & 27.5 & 0 & 0 \\
\hline
\end{tabular}

These are hidden costs, although the Omani fisherman is not obligated to pay, but this is a cost to the Omani economy. The Omani government can spend this money elsewhere that is beneficial to the welfare and development of the community. This can be very important for the fisherman and his family.

To optimize fishing, as far as possible, the use of fossil fuels, especially high-cost fuels such as gasoline, should be reduced.

\subsection{Air Pollution}

Fishing boats usually use two types of petrol engines to move at sea. The first type is Four-stroke engines; in the fourstroke gasoline engines, the power is produced in the cylinder in four stages: Suction, Compression, Combustion and Exhaust. The four-stroke engines have more complete combustion than two-stroke engines, and almost all induced air combines with fuel for proper combustion.

Since four-stroke engines have two-stroke more than two-stroke engines, the extra two-stroke consume power instead of producing power so, the four-stroke gasoline engines have less power than two-stroke engines of the same size. Therefore, they should have more cylinders to produce the same amount of power.

Oils for lubrication in four-stroke engines are separated from the combustion chamber. Therefore, the amount of burning oil associated with the fuel in them is very low. They have cleaner exhaust gas.

The second type is the Two-stroke engines; in the two-stroke gasoline engines, the power in the cylinder is produced in two stages: Suction and combustion. The lack of time to enter the air into the cylinder during suction stroke and proper mixing with the fuel impacts the proper combination. The fuel and air in this type of engine are not fully mixed and combusted, and the percentage of unburn fuel in two- stroke is more than four stroke engines. Two stroke engine can produce more power than four-stroke engines. Turbocharging systems are commonly used to optimize combustion in the two-stroke engines. In order to optimize lubrication in two-stroke engines, some fuel is added to the fuel, which burns with gasoline during combustion. This increases the contamination of the exhaust gas for two-stroke engines. Apart from this, when these types of engines are used for boats, burning on two-stroke and four-stroke engines create the following emissions, [13].

- Nitrogen oxides $\left(\mathrm{NO}_{\mathrm{x}}\right)$. Such emissions contain ozone and (secondary) particulate matter at ground level. NOx can also cause lung inflammation and disrupt the body's protection against respiratory infections such as pneumonia and influenza. 
- Carbon monoxide (CO). This colorless, odorless, and toxic gas is produced by burning of fossil fuels such as coal, which is mainly released from cars and trucks. CO removes the oxygen from the brain, heart and other important organs when inhaled.

- Sulfur dioxide $\left(\mathrm{SO}_{2}\right)$. Power plants and motor vehicles, particularly diesel and coal, produce this pollutant by burning sulfur-containing fuels. Sulfur dioxide can bind to form small particles in the environment which present the greatest health danger to young children which asthmatics, as many air contaminants.

- Greenhouse gases. Motor vehicles also emit pollutants which contribute to global climate change, primarily carbon dioxide. Indeed, tailpipe emissions from vehicles, vans and buses account for more than one-fifth of the overall global warming output in the United States; transport, which comprises planes, trains and ships, contributes for about 30 per cent of all heat-trapping gas emissions.

\subsection{Sea and Beach Pollution}

Vessels using gasoline engines have a tank for fuel storage. There is always the possibility of overflowing or leaking fuel to the sea. It is difficult to determine precisely the amount of fuel oil inside the tank due to floating movements, it increases the risk of overflowing.

Fuel is transferred to boats' fuel tanks by the hoses. Transfer of fuel by the hoses has leakage hazards to shore or sea.

Fuel may also spread to sea or shore due to damaged parts between the fuel tank and the engine such as hoses, filters, connectors and fuel pump. Repair of the engine or fuel transfer systems can cause pollution also.

Gasoline engines also need oil for lubrication. Therefore, the oil should be replaced at intervals. This change, if done with negligence, causes pollution for the beaches or the sea. Signs have been seen on the beaches.

\subsection{Noise Pollution}

Internal combustion engines generate a lot of noise. Many designs have been made to reduce the sound of these engines. Moreover, the engines are insulated by proper material to prevent transmission of the noise and sound. However, this noise is still in the boat, especially in the vicinity of the engine. The noise is much higher than the noise emission standards. Noise can have a negative effect on the fisherman or on the sea animals.

The excessive sound may cause deafness, neurological damage or both in humans. A loud sound may also increase blood pressure, blood glucose and cholesterol, anxiety and nervous discomfort.

Noise can change the lifestyle of aquatic animals. Published research from the University of Exeter on $6^{\text {th }}$ of June 2017 shows that the sound of motorboat engines shocked coral reef fish so dramatically that it altered parents' behavior and prevented male fish from properly protecting their children, eating and engaging with their offspring.

\subsection{Safety}

The safety can be enhanced by the use of electrical motors. they are simpler in design and construction. Less equipment is used in the electrical motors compare to the gasoline engines. Electric motors are almost maintenance- free.

The number of electric motors easily can be increased. Increase number of the electric motors can increase the 
safety of the voyage. For example, instead of one $30 \mathrm{~kW}$, the boat can be equipped with two $15 \mathrm{~kW}$ electrical motors independent of each other. If one electric motor fails, the boat can continue to run on the second motor and take the boat to the safe area.

The boats equipped with electric motor and batteries can move by solar charger in day time if the batteries are out of charge also, the solar cells can charge the batteries during the boat navigation to increase the batteries usages time.

Moreover, in the batteries operated boats, the exact amount of energy for moving the boat is displayed for the operator but, in fuel-related boats, it is very difficult to estimate the exact amount of fuel. The trim and the list of the boat create an error in the fuel display. It is experienced by the fisherman that they have found them out of fuel at the sea.

\subsection{Use of Electrical Motors for the Propulsion of the Boats}

The rapid progress of science in the current decades has provided us with the use of cheaper and cleaner energy. Electric motors that can be used on the boats are one of those improvements. These motors have a high degree of protection against the ingress of water and dust into them. Of course, using these motors without strong batteries is impossible. it is necessary to have a reliable source of electrical backup.

\subsubsection{Battery}

The technology has introduced the entry of these batteries for commercial use. Examples of such batteries are now available everywhere, especially in smartphones that have high energy consumption.

The new lithium batteries are absolutely safe for operation especially in the marine applications. The test has shown the proper performance of them. One of the most valuable features of these types of batteries is their lower weight than lead-acid batteries. The weight of lithium batteries is about one-third of conventional batteries. With this lower weight, they have better performance and can be recharged between 2000 and 5000 times, in average use, these results in usability of $10-15$ years. The new lithium batteries can deliver $100 \%$ of stored energy within themselves. It increases the total system performance and safety.

Lithium batteries are capable of receiving fast charging. This feature allows the boat to return fast to the operation. Also, the operator can have a spare set of the batteries to replace with discharged one for saving time and preventing discontinuity in the operation.

Lithium batteries are capable of being stored onboard in various arrangements. This feature provides the optimal use of boat space for cargo and passengers. Of course, the boat stability must always be considered.

Most of the conventional batteries' voltages drop under high loads. The drop in voltages increases the current to overcome the extra load. High current increases the temperatures and reduces lifetime of equipment. The lithium batteries have good steady voltages with fluctuating of the loads which render this battery a perfect source of power for electric boats.

Given the large number of cycles and the outstanding performance, these batteries reflect the most efficient expenditure relative to any other battery Technology.

The lithium batteries should be equipped with a Battery Management System (BMS). Every cell should be controlled individually and monitored. It means that the system is equipped with a Liquid Crystal Display (LCD) guide 
displaying the relevant details such as:

- Overall output of the battery, it is a good indication for the best performance of the electric motor.

- The voltage of the best and the worst cell, it makes the maintenance much easier. The operator can identify the defected cell and perform the remedial action.

- Charging and discharging current, it also shows the healthiness of total and individual part in the system.

- Charged and discharged ampere- hours, the operator always knows how many hours more he can run the boat safely or extend the running hours by reducing the boat speed.

The BMS regulates the rechargeable battery and the engine controller. It prevents overcharging or overcharging.

Table No.3 shows the specification of some available batteries in the market: (aquawatt)

Table 3: Battery Specification, [2]

\begin{tabular}{|c|c|c|}
\hline Size & Weight & Energy \\
\hline $1400 \times 750 \times 330 \mathrm{~mm}$ & $340 \mathrm{Kg}$ & $29 \mathrm{~kW} / \mathrm{h}$ \\
\hline $1110 \times 950 \times 330 \mathrm{~mm}$ & $340 \mathrm{Kg}$ & $29 \mathrm{~kW} / \mathrm{h}$ \\
\hline $1870 \times 580 \times 330 \mathrm{~mm}$ & $340 \mathrm{Kg}$ & $29 \mathrm{~kW} / \mathrm{h}$ \\
\hline $980 \times 740 \times 330 \mathrm{~mm}$ & $265 \mathrm{Kg}$ & $23 \mathrm{~kW} / \mathrm{h}$ \\
\hline $1200 \times 580 \times 330 \mathrm{~mm}$ & $265 \mathrm{Kg}$ & $23 \mathrm{~kW} / \mathrm{h}$ \\
\hline $1760 \times 590 \times 330 \mathrm{~mm}$ & $265 \mathrm{Kg}$ & $23 \mathrm{~kW} / \mathrm{h}$ \\
\hline$-144 \mathrm{~V} 200 \mathrm{Ah}$ for Green Flash outboard engine $35 \mathrm{minutes}$ at full power or 1 hour at 29 \\
$\mathrm{~kW}$ or 2 hours at $14,5 \mathrm{~kW}$ or 4 hours at $7 \mathrm{~kW}$ or 8 hours at $3,5 \mathrm{~kW}$ \\
$-144 \mathrm{~V} \mathrm{160} \mathrm{Ah} \mathrm{for} \mathrm{Green} \mathrm{Flash} \mathrm{outboard} \mathrm{engine} 25 \mathrm{minutes}$ at full power or 1 hour at 23 \\
$\mathrm{~kW}$ or 2 hours at $12 \mathrm{~kW}$ or 4 hours at $6 \mathrm{~kW}$ or 8 hours at $3 \mathrm{~kW}$
\end{tabular}

\subsubsection{Electric Motor}

Most of the electric motors for the boat and ship's propulsion system are three-phase or single-phase induction motor. Induction motors are robust and simple in construction with very few moving parts and brushless, therefore, there is no connection between their rotor and stator.

Produced torque in the rotor is obtained by electromagnetic induction. The stator has to create such magnetic field by its winding. Depend on the type of the induction motors, the wires are winded on the stator slots and connected to Alternative Current (AC) supply. Stator produces a magnetic rotating field; it induces in the conductor bars of the rotor an opposing current. The induced currents in the rotor create in the rotor magnetic fields that react against the magnetic field of the stator. The opposite of two magnetic fields result in rotation of the rotor. The speed of rotation depends on the number of the poles on the stator and the AC Supply Frequency. Since the poles number in motors is usually fixed, control of the speed is done by changing the electrical supply frequency (variable-frequency drive).

Three-phase induction motors have the rotating magnetic field on their stator. Therefore, when the stator is connected to the AC power supply the rotor starts to rotate, but the single-phase induction motors require an external starter for initial rotation.

Induction motors can operate efficiently in a rough and humid environment such as in seagoing ships. They require less maintenance comparing to Direct Current DC motors or synchro motors, they do not have slip rings, brushes or 
commuters.

Currently, a wide range of electric motors as boat propulsion system are available in the market, from 1 HP to 80 HP which covers all types of fishing and pleasure boats. They are made of aluminum or stainless steel to be seawater resistance. The zinc anodes are provided for them to reduce the rate of corrosion and give facility if seawater is needed for cooling the motor.

As mentioned before the electric motors run very smoothly. They do not produce any noise or sound. Electric motors can reach to their maximum speed fast and the control lever can be engaged at any time for instant forward or reverse propulsion and it is not required any warmup. Electric motors achieve instant torque with Electromotive Force while internal combustion engines require building RPMs gradually when raising piston firing frequency.

\section{CONCLUSIONS}

Technology gives us the chance to move towards clean energies. Market demand will bring innovations. At the moment, moving towards electric propulsion for vessels is justifiable. And in the very near future, in addition justification will be more economical and more comfortable. This change should begin as soon as possible. Dependence on fossil fuels needs to be reduced. Oil pollution should be cleared off the coast and we must not give the chance of pollution to our environment. The electric propulsion system helps us to reduce oil pollution, air pollution and noise pollution. This paper provides necessary information to the people who in position to decide for a change.

\section{ACKNOWLEDGMENT}

This research paper on "Electric Propulsion for Near Coastal Ships" would not be possible without the support, assistance and guidance of colleagues and the leading companies in the electrical propulsion system.

I would like to acknowledge and show my gratitude to the management of International Maritime College Oman along with the Dr. Kambiz, Head of Maritime Department for supporting me to overcome the task. I would like also to show my appreciation and gratitude to Mr. Dieter H. Seebacher from Aquawatt (Green Marine Technologies) and Mr. Eelke Sijbrandij, Mr. Roy Arzilio Po’ and Mr. Adarsh Suresh from Exalto-emirates.

\section{REFERENCES}

1. Exalto Emirates General Trade Catalogue 2019. Available at: http://catalogue.exalto-emirates.com/211/\#zoom=z (Accessed: 31 July 2019).

2. Aquawatt electric yachts, electric boats, electric boat motors, solarpowered vessels, solarpowered yachts - Green Marine Technologies. Available at: http://www.aquawatt.at/GB/startseite_GB.html (Accessed: 31 July 2019).

3. Leśniewski, Wojciech, Piatek Daniel, Marszatkowski Konrad, Litwin Wojciech. (2020). Small Vessel with Inboard Engine Retrofitting Concepts; Real Boat Tests, Laboratory Hybrid Drive Tests and Theoretical Studies. Energies (19961073). Vol. 13 Issue 10, p2586. $1 p$. Retrieved on 15 May $2020 . \quad$ Available at: https://www.masader.om/eds/detail? $d b=e n r \& a n=143637563 \& i s b n=19961073$

4. Obaid, Waleed; Hamid, Abdul-Kadir; Ghenai, Chaouki. (2018). Hybrid PEM Fuel-Cell-Diesel-Solar Power System Design with 
Fuzzy Battery Management System and Weather Forecasting for Electric Boats. $20186^{\text {th }}$ International Renewable and Sustainable Energy Conference (IRSEC) Renewable and Sustainable Energy Conference (IRSEC), $20186^{\text {th }}$ International. :1-7

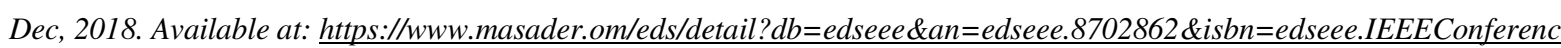

5. Antoniuk, Alexei V.; Lukichev, Andrey N._(2018). Development of an electric-driven shipbome launching device, IEEE Conference of Russian Young Researchers in Electrical and Electronic Engineering (EIConRus) Young Researchers in Electrical and Electronic Engineering (EIConRus), 2018 IEEE Conference of Russian. :861-864 Jan, 2018. Available at: https://www.masader.om/eds/detail? $d b=e d s e e e \& a n=e d s e e e .8317224 \& i s b n=e d s e e e$. IEEEConferenc

6. Leung, C. P.; Cheng, K. W. E. (2017). Zero emission solar-powered boat development. 2017 7th International Conference on Power Electronics Systems and Applications - Smart Mobility, Power Transfer \& Security (PESA) Power Electronics Systems and Applications - Smart Mobility, Power Transfer \& Security (PESA), 2017 7th International Conference on. :1-6 Dec, 2017. Available at: https://www.masader.om/eds/detail?db=edseee \&an=edseee.8277736\&isbn=edseee.IEEEConferenc.

7. Hossain, M.S.; Baque Billah, S.M.; Barua, S.; Mahmud, M.S.; Khadem, T. (2017). Life cycle cost analysis of solar-LED alternatives to fuel-based fishing net indicator. 2017 International Conference on Innovations in Green Energy and Healthcare Technologies (IGEHT) Innovations in Green Energy and Healthcare Technologies (IGEHT), 2017 International Conference on. $: 1-4$
Mar,
2017.
Available
at:

https://www.masader.om/eds/detail? db=edseee\&an=edseee. $8093981 \& i$ isbn=edseee.IEEEConferenc

8. Camara, M.B.; Dakyo, B. (2016). Real time energy management for hybrid electric boat applications - Using variable speed diesel generator and lithium-battery. 2016 IEEE International Conference on Automation, Quality and Testing, Robotics (AQTR) Automation, Quality and Testing, Robotics (AQTR), 2016 IEEE International Conference on. :1-6 May, 2016. Available

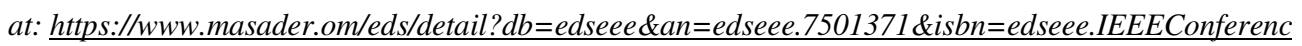

9. Larson, Andrew; Dietz, Eric. (2015). A Viability Study of a Lithium Battery Powered Golf Cart. GSTF Journal of Engineering Technology; Jul2015, Vol. 3 Issue $2, \quad$ p49-52, 4 . Available at: https://www.masader.om/eds/detail $?$ db=aci\&an=110336240\&isbn=22513701

10. Bellache, K.; Camara, M.B.; Dakyo, B. (2015). Hybrid Electric Boat based on variable speed Diesel Generator and lithiumbattery - using frequency approach for energy management. 2015 Intl Aegean Conference on Electrical Machines \& Power Electronics (ACEMP), 2015 Intl Conference on Optimization of Electrical \& Electronic Equipment (OPTIM) \& 2015 Intl Symposium on Advanced Electromechanical Motion Systems (ELECTROMOTION) Electrical Machines \& Power Electronics (ACEMP), 2015 Intl Conference on Optimization of Electrical \& Electronic Equipment (OPTIM) \& 2015 Intl Symposium on Advanced Electromechanical Motion Systems (ELECTROMOTION), 2015 Intl Aegean Conference on. :744-749 Sep, 2015. Available at: https://www.masader.om/eds/detail?db=edseee \&an=edseee.7427045\&isbn=edseee.IEEEConferenc 
11. Yildiz, Faruk, Coogler, Keith L., Amador Ruben. (2015). Conversion of a Gasoline-Powered Boat to a Hybrid Electric Boat. Journal of Engineering Technology, Vol. 32 Issue 1, p52-63, 12p, Spring 2015. Available at: https://www.masader.om/eds/detail?db=aci\&an=102894411\&isbn=07479964[12] TRADING ECONOMICS | 20 million INDICATORS FROM 196 COUNTRIES (2019).

12. Available at: https://tradingeconomics.com/ (Accessed: 21 June 2019).

13. Cars, Trucks, Buses and Air Pollution | Union of Concerned Scientists (2019).

14. Available at: https://www.ucsusa.org/clean-vehicles/vehicles-air-pollution-and-human-health/cars-trucks-air-pollution (Accessed: 22 June 2019). 